American Journal of Agricultural and Biological Sciences 3 (3): 526-533, 2008

ISSN 1557-4989

(C) 2008 Science Publications

\title{
Effects of Different Concentrations and Applications of Calcium on Storage Life and Physicochemical Characteristics of Papaya (Carica Papaya L.)
}

\author{
${ }^{1}$ Mahmud, T.M.M., ${ }^{1} \mathrm{Al}$ Eryani-Raqeeb, A., ${ }^{2}$ Syed Omar, S.R., ${ }^{3}$ Mohamed Zaki, A.R and \\ ${ }^{4}$ Al Eryani, Abdul-Rahman \\ ${ }^{1}$ Department of Crop Science, \\ ${ }^{2}$ Department of Land Management, Faculty of Agriculture, \\ ${ }^{3}$ Department of Chemistry, Faculty of Science, University Putra Malaysia, \\ ${ }^{4}$ Department of Agronomy, Faculty of Agriculture, Sanaa University, Yemen
}

\begin{abstract}
Papaya (Carica Papaya L.) fruits index 2 were treated with 1.5, 2.5 and 3.5\% solutions of calcium chloride by dipping and vacuum infiltration $(-33 \mathrm{Kpa})$ or untreated $(0 \%)$ as control. Effects of these treatments were evaluated on storage life and postharvest quality characteristics of papaya. After 21 days of storage at $13 \pm 1^{\circ} \mathrm{C}$, the fruits were removed from storage for physicochemical analysis. Following additional five days holding in the storage condition for fruits used for evaluation of the rate of disease incidence and storage life. Postharvest dip treatments at different concentrations of calcium prolonged storage life, slowed down the ripening processes and maintained the quality of papaya. Whereas, it was effectively greater with calcium infiltration treatments than that for dip treatments. Calcium infiltration extended the storage life and retained the quality as calcium concentrations increased up to $2.5 \%$ and then declined. The desired effect was obtained at $2.5 \%$ infiltration compared with other treatments. The least disease incidence was found in those fruits infiltrated with $2.5 \%$ calcium. Hence, it can be concluded that postharvest infiltration of calcium at $2.5 \%$ has the potential to control disease incidence, prolong the storage life and preserve valuable attributes of postharvest papaya, presumably because of its effects on inhibition of ripening and senescence process and loss of the fruit firmness of papaya.
\end{abstract}

Key words: Papaya, postharvest, calcium chloride, papaya storage life, papaya quality

\section{INTRODUCTION}

Papaya (Carica papaya L.) is one of the main fruits of Malaysia. Cultivar Eksotika II has gained popularity in the domestic and export markets ${ }^{[47]}$. However, the short storage life limits the export of the fruits to distant markets by refrigerated sea containers. The ripe fruits soften rapidly and are easily infected by diseases and proned to chilly injuries as a result of exposure to low temperatures. Therefore, owing to its high perishability there is much wastage ${ }^{[47]}$.

The role of calcium in the physiology of plant tissue is well established ${ }^{[5]}$. In addition to its involvement in cell wall membrane and chromosome, metabolism it contributes to the maintenance of configuration of specific enzymes ${ }^{[22]}$. Addition of calcium improves rigidity of cell walls and obstruct enzymes such as polygalcturonase from reaching their active sites ${ }^{[21]}$, thereby retarding tissue softening and delaying ripening. Calcium inhibits the ripening of tomato and pineapples ${ }^{[16,49]}$. Its role in physiological disorders is related to shelf life, ripening and fruit quality $^{[50]}$.

Calcium as postharvest treatment has been used as firming agents to extend postharvest shelf life in whole and fresh cut fruits. Rosen and $\mathrm{Kader}^{[37]}$ found that $\mathrm{CaCl}_{2}$ treated strawberries by dipping resulted in higher calcium content and were firmer than water dipped. Agar et al ${ }^{[2]}$ also found $\mathrm{CaCl}_{2}$ maintained the firmness throughout storage for kiwifruits dipped in 0.5 or $1 \%$ $\mathrm{CaCl}_{2}$. It was also reported that the rate of fruit softening depends on fruit calcium status.

Postharvest treatments of fruits with low concentrations of calcium salts have been found to reduce physiological disorders and delay senescence ${ }^{[8]}$. Postharvest calcium dips can increase calcium content considerably compared to preharvest sprays, without causing fruit injury, depending on salt type and calcium concentration. Postharvest calcium application maintains cell turgor, membrane integrity, tissue

Corresponding Author: Abdul Raqeeb Al Eryani, Faculty of Agriculture, University of Putra Malaysia (UPM) Tel: +6012-6770916 Fax: +603-89435973 
firmness and delays membrane lipid catabolism thus extending storage life of fresh fruits ${ }^{[5,33]}$.

Most early workers applied calcium by dipping fruits in solutions of calcium salts, but more recent works have shown that vacuum infiltration of these solutions maybe a more effective method of getting calcium into the fruits ${ }^{[24,38]}$. Infiltrated solutions also retain much of their effectiveness when the fruits are rinsed with water following treatment to reduce the possibility of injury to the fruit or damage ${ }^{[43]}$. Although most efforts in treating fruit with calcium solutions have been directed towards reducing losses due to physiological disorders, it has been reported that increased calcium content of fruit may also reduce losses due to decay causing organisms ${ }^{[45]}$. However, few works have focused on storage life and compositional changes of fruits ${ }^{[4,13,19]}$.

In India, few researches have been done on papaya using calcium dip application on storage life and some aspects of quality. There was positive effects on prolonging storage life and maintained the quality aspects using dip treatment ${ }^{[23,34]}$. Therefore, needs for research using different applications (dip and vacuum infiltration) and concentrations need to be carried out to evaluate their effects and to optimize the best application techniques and concentration on extending storage life, control of postharvest disease incidences and maintaining quality characteristics of papaya cv Eksotika II is inevitable.

The objectives of this study are to determine the effects of different postharvest calcium applications and concentrations on storage life, disease incidences and quality aspects such as weight loss, firmness, color changes, soluble solids concentrations, $\mathrm{pH}$, titratble acidity and ascorbic acid of papaya and to evaluate for optimum application and concentration of treating fruits with calcium solutions.

\section{MATERIALS AND METHODS}

Plant material and treatments: Papaya fruits were treated with commercial grade of calcium chloride $74 \%$ made up as $1.5,2.5$ and $3.5 \%$ solutions with distilled water and $0.03 \%$ of Tween 80 as surfactant agent. Dipping and vacuum infiltrations Methods were used for treatment with each concentration of the calcium solutions. Treatments involved placing the fruits in solutions for $10 \mathrm{~min}$ for dipping. Fruits were vacuum infiltrated by placing in calcium solutions for $10 \mathrm{~min}$ under $-33 \mathrm{Kpa}$ vacuum and then held in solution for 5 min after vacuum was released. After each treatment, the fruits were air dried at ambient temperature for 30 min in an attempt to reduce possible chemical injury.
Control treatment was the untreated fruits for comparison of both methods. Two lots of twenty five fruits for each treatment were used. Following treatment, the fruits were sleeved with white styrofoam nettings. Fruits were then packed in single layer with stem end facing down in a commercial export packaging cartons and stored at $13 \pm 1^{\circ} \mathrm{C}$ and relative humidity at $80-90 \%$ for 26 days of storage.

Fruit quality evaluation: Disease incidence (DI) was monitored by determined the number of fruits showing the visible symptoms of anthracnose lesions on the surfaces of fruits and recording the percentage. Storage life was monitored and records were taken until the end of storage and expressed by day of storage. Weight loss was also determined. Five fruits in each replication for each treatment were marked before storage and weighed using electronic balance (EK-600H, Japan). At each storage interval ( 7 days), fruits were taken out from cold storage and weighed. Immediately after weighing, they were kept at cold storage refrigerator for subsequent weighing. Percentage of weight loss at a particular storage interval was determined.

Fruit firmness was measured by the Instron Universal Testing Machine (Model 5540, USA) using the compression mode. The test was done on five fruits in each replication by using probe diameter size of 50 $\mathrm{mm}$, speed $50 \mathrm{~mm} / \mathrm{minute}$ and load range 100 load cells. Compression force was measured at the maximum peak of recorded force on the chart and expressed as Newton $(\mathrm{N})$.

Peel colour of the fruits was determined using a Minolta CR-300 Chroma Meter (Minolta Corp., Japan). The peel colour determination was expressed in chromaticity values of $\mathrm{L}^{*}, \mathrm{C}^{*}$ and $\mathrm{h}^{\circ}$. The $\mathrm{L}^{*}$ coordinate indicated the lightness of colour with value ranging from $0=$ black to $100=$ white. $\mathrm{C}^{*}=$ $\left(\mathrm{a}^{* 2}+\mathrm{b}^{* 2}\right)^{1 / 2}$ which represented the hypotenuse of a right triangle with values ranging from $0=$ least intense to 60 $=$ most intense $h^{\circ}$, referred to as colour, was the angle of tangent ${ }^{-1} \mathrm{~b}^{*} / \mathrm{a}^{*}$ where $0^{\circ}=$ red purple, $90^{\circ}=$ yellow, $180^{\circ}=$ bluish- green and $270^{\circ}=$ blue.

Soluble solids concentrations, pH, titratable acidity and ascorbic acid: After 21 days of storage, soluble solid content (SSC), pH, titratable acidity and ascorbic acid of fruit pulp were analysed according to the method of Ranganna ${ }^{[35]}$. SSC $\left(\right.$ Brix $^{\circ}$ ) was determined with a Baush Lomb Abbe $3 \mathrm{~L}$ digital refractometer (Rochester, NY). The refractometer was calibrated with distilled water before reading. Ten $g$ of pulp tissues were homogenized using a kitchen blender with $40 \mathrm{~mL}$ of distilled water. The mixture was filtered through 
cotton wool. A drop of the filtrate was then placed on the prism glass of the refractometer to obtain the $\left(\mathrm{Brix}^{\circ}\right)$ reading. The readings were multiplied by dilution factor to obtain the original percent SSC of the papaya pulp.

Fruit juice $\mathrm{pH}$ determination was determined by using the remainder of the filtrate from SSC determination using $\mathrm{pH}$ meter model Crison Micro $\mathrm{pH}$ 2000, Crison Instruments, Spain. pH meter was calibrated by using buffer solutions of $\mathrm{pH} 4$ and 7 .

Titratable acidity was analyzed using the titration method. Fruit pulp tissues ( $10 \mathrm{~g}$ ) from five papaya fruits were homogenized with $40 \mathrm{~mL}$ of distilled water using kitchen blender, the mixture was filtered through cotton wool. Five $\mathrm{mL}$ of the filtrate with one to two drops of phenolphthalein $(1 \%)$ as indicator was titrated using 0.1 $\mathrm{N} \mathrm{NaOH}$ to an endpoint pink ( $\mathrm{pH} 8.2$ ). The results were expressed as percentage of citric acid per $100 \mathrm{~g}$ fresh weight.

Ascorbic acid was determined using the Dye method $^{[35]}$. Fruit pulp tissues $(10 \mathrm{~g})$ from five papaya fruits were homogenized with $90 \mathrm{~mL}$ of $3 \%$ metaphosphoric acid $\left(\mathrm{HPO}_{3}\right)$ using a kitchen blender, the mixture was filtered through cotton wool. Five $\mathrm{mL}$ of aliquot was titrated with a standard dye solution (2, 6-dichlorophenol-indophenol) to a pink colour that persisted for 15 seconds. The ascorbic acid content (Vitamin C) was expressed as $\left(\mathrm{mg}^{-1} 100 \mathrm{~g}\right)$ of fresh fruits.

Statistical analysis: The experimental design was complete randomized design (CRD) with five replicates. Analysis of variance (ANOVA) was used to detect treatment effect. Mean separation were performed by using least significance difference (LSD) at the $\mathrm{p} \leq 0.05$ level. The data were analyzed using Statistical Analysis System (SAS) version 8.2 $2^{[42]}$.

\section{RESULTS AND DISCUSSION}

Storage life: Storage life was extended significantly $(\mathrm{p}<0.001)$ to maximum duration of 25.9 days using calcium infiltration at $2.5 \%$ compared to other treatments (Table 1). Storage life was significantly prolonged using calcium infiltration treatments at 3.5 and $1.5 \%$ and dip treatment at $2.5 \%$ by $22.7,22.2$ and 21.3 days, respectively compared to the untreated fruit (control), but no significant difference between treatments excluding control. Dip treatments at 3.5 and $1.5 \%$ tended to prolong the storage life, respectively, but they did not show significant increase compared to untreated fruit which lasted for 17.5 days of storage.

It was found that the application of calcium prolonged the shelf life of strawberries, as measured by a delay in accumulation of sugars, decrease in organic acids, increase of color saturation index and mold development $^{[7]}$.

Table 1: Effects of different concentrations and applications of calcium on storage life after 26 days and firmness after 21 days of storage of papaya fruits at $13 \pm 1^{\circ} \mathrm{C}$

\begin{tabular}{llll}
\hline Treatments & & Storage life (day) & Firmness (N) \\
\hline Control & $0 \%$ & $17.46 \mathrm{~d}$ & $1.36 \mathrm{f}$ \\
Dip & $1.5 \%$ & $19.40 \mathrm{~cd}$ & $1.83 \mathrm{ef}$ \\
& $2.5 \%$ & $21.27 \mathrm{bc}$ & $2.63 \mathrm{~d}$ \\
Infiltration & $3.5 \%$ & $20.10 \mathrm{bcd}$ & $1.95 \mathrm{e}$ \\
& $1.5 \%$ & $22.16 \mathrm{bc}$ & $3.16 \mathrm{c}$ \\
& $2.5 \%$ & $25.93 \mathrm{a}$ & $5.37 \mathrm{a}$ \\
LSD & $3.5 \%$ & $22.67 \mathrm{~b}$ & $3.95 \mathrm{~b}$ \\
\hline
\end{tabular}

Means with the same letters within column are not significantly different at $\mathrm{p} \leq 0.05$ using LSD. Each value is the mean for five replicates

Morris et al. ${ }^{[32]}$ and Rosen and Kader ${ }^{[37]}$ reported that calcium chloride dip treatment can help maintain firmness and visual quality resulting in a longer shelf life of strawberry. Suntharalingam ${ }^{[48]}$ reported that calcium postharvest dip treatments at 4 and $5 \%$ increased the shelf life of mangoes fruit under both ambient and cold storage conditions without causing skin injury.

Firmness: Calcium infiltration treatment at $2.5 \%$ significantly affected firmness followed by calcium infiltration treatments at 3.5 and $1.5 \%$, respectively compared with control treatment after storage (Table 1). However, the infiltration treatment at $2.5 \%$ demonstrated the best effect on maintaining fruit firmness compared with other treatments. Calcium dip treatment at $2.5 \%$ significantly improved maintenance of fruit firmness followed by dip treatment at $3.5 \%$ compared to control treatment, but they were less than that obtained with infiltration treatments. Calcium dip treatments at 3.5 and $1.5 \%$ provided the same firming effect, but maintenance of firmness tended to be higher in $3.5 \%$ treated samples compared with the control treatment. Although initially higher than water dipped samples, firmness of just cut samples decreased faster than all other samples throughout the 12 days of storage in both experiments. The control treatment had the lowest ability in maintaining firmness followed by the lower concentration $1.5 \%$ dip treatment, where they did not showed any significance difference among each other. The desired effect of calcium infiltration at $2.5 \%$ on maintaining fruit firmness may be due to the calcium binding to free carboxyl groups of polygalacturonate polymer, stabilizing and strengthening the cell walls ${ }^{[9]}$. 
A firming effect by a combination of calcium chloride dip and heat treatment has also been shown in fresh cut melons by Luna-Guzman et al. ${ }^{[28]}$. The effect of calcium in tissue firmness is generally explained by complexing cell wall and middle lamella polygalacturonic acid residues imparting improvement of structural integrity ${ }^{[31]}$. The deesterified pectin chains may crosslink with either endogenous calcium or added (exogenous) calcium to form a tighter, firmer structure $^{[17]}$. However, calcium ions may also impact tissue firmness by contributing to increase membrane integrity and the consequent maintenance or increase of cell turgor pressure ${ }^{[30]}$.

These results may indicate that the firming effect is accompanied by improved water holding capacity due to a more crosslinked pectin network; thus, less juice is released when biting through calcium treated papaya fruit. Additionally, higher water holding capacity could be related to increased firmness due to higher turgor pressure which is supported by higher moisture content and hardness attributes obtained with infiltration treatment at $2.5 \%$. Picchioni et al. ${ }^{[33]}$ found that $\mathrm{CaCl}_{2}$ (2\% or $4 \%$ ) keep the Golden Delicious apple firm during 6 month of storage as compared to untreated fruit.

Weight loss: Weight loss was observed to increase by increasing calcium concentrations and storage time as shown in Table. 2. Weight loss was $(\mathrm{p}<0.001)$ higher in untreated fruit, calcium dip treatments and lower concentration of infiltration treatment (1.5\%) compared with other treatments. However, there was no significant different between those treatments among each other after three weeks of storage. Calcium infiltration treatments at concentrations 2.5 and 3.5\% decreased the weight loss progressively compared to the other treatments. Whereas, $2.5 \%$ infiltration treatment showed higher ability in reducing weight loss significantly compared with other treatments. The decline in weight loss using calcium infiltration at 3.5\% observed might be that higher concentration caused hydration and that for $2.5 \%$.

It was reported that pressure infiltration of $2 \%$ $\mathrm{CaCl}_{2}$ was optimal for maintaining the texture of Golden Delicious apples during 6 months storage ${ }^{[1]}$, especially by maintaining fruit water relations (by decreasing air space volume) while minimizing the risk of salt related injuries ${ }^{[38]}$. Lester and Grusak ${ }^{[27]}$ have shown that calcium application was effective in terms of membrane functionality and integrity maintenance, with lower losses of phospholipids and proteins and reduced ion leakage which could be responsible for the lower weight loss found in calcium treated plums.
Table 2: Effects of different concentrations and applications of calcium on weight loss of papaya fruits after 21 days of storage at $13 \pm 1^{\circ} \mathrm{C}$

\begin{tabular}{lllll}
\hline Treatments & & \multicolumn{3}{c}{ Weight loss $(\%)$} \\
& & 7 days & 14 days & 21 days \\
\hline Control & $0 \%$ & $6.27 \mathrm{a}$ & $8.26 \mathrm{a}$ & $10.12 \mathrm{a}$ \\
Dip & $1.5 \%$ & $5.73 \mathrm{ab}$ & $8.10 \mathrm{a}$ & $10.02 \mathrm{a}$ \\
& $2.5 \%$ & $5.05 \mathrm{bc}$ & $7.15 \mathrm{~b}$ & $9.77 \mathrm{a}$ \\
& $3.5 \%$ & $5.16 \mathrm{bc}$ & $7.50 \mathrm{ab}$ & $9.95 \mathrm{a}$ \\
Infiltration & $1.5 \%$ & $4.77 \mathrm{c}$ & $6.88 \mathrm{~b}$ & $9.50 \mathrm{ab}$ \\
& $2.5 \%$ & $2.78 \mathrm{~d}$ & $4.51 \mathrm{c}$ & $6.87 \mathrm{c}$ \\
& $3.5 \%$ & $3.03 \mathrm{~d}$ & $5.02 \mathrm{c}$ & $8.60 \mathrm{~b}$ \\
LSD & & 0.85 & 0.89 & 1.14 \\
\hline
\end{tabular}

Means with the same letters within a column are not significantly different at $\mathrm{p} \leq 0.05$ using LSD. Each value is the mean for five replicates

Izumi and Watada ${ }^{[20]}$ have studied the effect of calcium on the storage quality of sticks, sliced and shredded carrots. The difference between the control and the treated carrots with $1 \% \mathrm{CaCl}_{2}$ solution, like the effects on the texture and weight loss, was greater at the extended period of storage. This inhibitory effect of calcium chloride is attributed probably to the increased resistance of tissues to the bacterial infection rather than to a bactericidal action.

Peel color changes: Color is one of the most important visual attributes of papaya. The $\mathrm{L}^{*}$ value, representing the lightness of color, was 65.03 in control treatment fruit and $\mathrm{L}^{*}$ along with a hue value of 86.92 and chroma of 57.95, indicate yellow color of fruit (Table 3 ). In calcium dipped fruit at $2.5 \%$, the $L^{*}$ value decreased up to 61.0 , chroma 54.24 and increased the hue $^{\circ}$ to 93.80 , indicating a lower development of yellow color compared with other dip treatments 3.5\% and $1.5 \%$ and control treatment, respectively. Fruit infiltrated with $3.5 \%$ and $1.5 \%$ had lower values in lightness and chroma values and higher values of hue compared with dip treatment at $3.5 \%$ but they did not show any significant difference between each other. Whereas, the infiltration treatment at $2.5 \%$ had lower lightness and chroma (51.34 and 46.59) and higher hue ${ }^{\circ}$ (103.99) values significantly $(\mathrm{p}<0.001)$ compared with other treatments. This treatment affected the peel color development, resulting in a significant variation of lightness, chroma and hue values. This affected the characteristic yellowness which resulted in delaying ripening process of papaya fruit.

The variance in development of color compared with control shows that calcium retards the ripening processes, perhaps by inhibiting the metabolic systems that initiate ripening. Our results confirmed that application of calcium chloride delays the fruit ripening development on strawberries ${ }^{[6]}$. Haard ${ }^{[18]}$ reported that 
calcium application caused a reduction of color development of apple, the decrease in saturation color index by the end of storage may be indicative of the darker color of senescing fruit.

Our results are consistent with the findings of Suntharalingam ${ }^{[48]}$ who reported that color development of mangoes fruit were retarded significantly using calcium chloride treatment compared with the control under both ambient and cold storage conditions.

Table 3: Effects of different concentrations and applications of calcium on peel color lightness $\left(\mathrm{L}^{*}\right)$, chroma $\left(\mathrm{C}^{*}\right)$ and hue angle $\left(\mathrm{h}^{\circ}\right)$ of papaya fruits after 21 days of storage at $13 \pm 1^{\circ} \mathrm{C}$

Treatments Color changes

\begin{tabular}{|c|c|c|c|c|}
\hline & & & \\
\hline & & Lightness $\left(\mathrm{L}^{*}\right)$ & Chroma $\left(\mathrm{C}^{*}\right)$ & Hue $\left(h^{\circ}\right)$ \\
\hline Control & $0 \%$ & $65.03 \mathrm{a}$ & $57.95 \mathrm{a}$ & $86.92 \mathrm{e}$ \\
\hline \multirow[t]{3}{*}{ Dip } & $1.5 \%$ & $63.12 \mathrm{ab}$ & $55.38 \mathrm{ab}$ & $88.78 \mathrm{de}$ \\
\hline & $2.5 \%$ & $61.00 \mathrm{bc}$ & $54.24 b c$ & $93.80 \mathrm{c}$ \\
\hline & $3.5 \%$ & $62.25 \mathrm{ab}$ & $54.95 \mathrm{ab}$ & $92.28 \mathrm{~cd}$ \\
\hline \multirow[t]{3}{*}{ Infiltration } & $1.5 \%$ & $58.00 \mathrm{~cd}$ & $52.84 \mathrm{bc}$ & $95.52 \mathrm{bc}$ \\
\hline & $2.5 \%$ & $51.34 \mathrm{e}$ & $46.59 \mathrm{~d}$ & $103.99 \mathrm{a}$ \\
\hline & $3.5 \%$ & $56.77 \mathrm{~d}$ & $50.61 \mathrm{c}$ & $98.96 \mathrm{~b}$ \\
\hline LSD & & 3.4 & 3.7 & 4.7 \\
\hline
\end{tabular}

Means with the same letters within a column are not significantly different at $p \leq 0.05$ using LSD. Each value is the mean for five replicates.

Soluble solids concentrations: Untreated and calcium dip treatments were obtained to have the higher content of SSC but they did not show any significance difference between each other (Table 4). Significant $(\mathrm{p}<0.001)$ increase in SSC was observed for calcium infiltration treatment at $1.5 \%$ than calcium dip treatment at $3.5 \%$. However, it was not significantly different with $2.5 \%$ dip treatment where the SSC was affected more compared with control treatment. Whereas, calcium dip at $1.5 \%$ and control treatments effects SSC content were similar. Calcium infiltration treatments at $2.5 \%$ and $3.5 \%$ significantly lowered contents of SSC compared to other treatments.

The effect of calcium in reducing SSC content of fruits was probably due to slowing down respiration and metabolism activity hence, retarding the ripening process. The slower respiration also slows down the synthesis and use of metabolites resulting in lower SSC due to the slower change from carbohydrates to sugars $^{[36]}$. Our results are in line with that obtained by Cheour et al. ${ }^{[7]}$ who reported that the concentration of free sugars progressively increased with storage, this increase was quite markedly delayed by calcium treatment for Glooscap variety of strawberry. Cheour et $a l .{ }^{[6]}$ reported that the application of calcium on strawberry plants increased fruit calcium content and influenced several postharvest senescence changes involving free sugars, organic acids, anthocyanin content and texture of fruits.
pH: Untreated fruit was observed to have the higher content of $\mathrm{pH}$ compared with other treatments (Table 4). Calcium infiltration treatment at 2.5, 3.5 and $1.5 \%$ proved to be better in maintaining low $\mathrm{pH}$ significantly, compared with untreated fruit with no differences among each others. Dip treatments at 2.5, 3.5 and $1.5 \%$ showed less effect in maintaining $\mathrm{pH}$ content respectively with significant difference compared to untreated fruit but they did not show any variances among each other. So in this respect our results have shown that there is no significant effects on $\mathrm{pH}$ by increasing calcium concentration for both dip and infiltration applications whereas, calcium infiltration treatments maintained lower $\mathrm{pH}$ more than those of dip treatments.

These results are consistent with findings of Andrea et $a l .{ }^{[3]}$ who reported that the postharvest application of calcium chloride in strawberry fruits reduced fruits $\mathrm{pH}$ between the second and the fourteenth day, following an increase of the same, but did not show statistical difference.

Besides the fact that calcium increased proportionately with the increment of the degree of immersion, it did not significantly affect the acidity and $\mathrm{pH}$ possibly due to the cells protection and maintenance of ideal $\mathrm{pH}$ conditions for its proper functioning. Coseteng and Lee ${ }^{[12]}$ reported that the organic acids in papaya are largely citric and malic acids and the increase in $\mathrm{pH}$ during ripening and storage was due to the metabolic processes of the fruit that resulted in a decrease of the organic acids.

Titratable acidity: Postharvest infiltration treatment with $2.5 \%$ had the highest titratable acidity (TA) level $(\mathrm{p}<0.001)$ compared with other treatments (Table 4). The lowest level of TA was obtained with untreated fruit followed by calcium dip treatment at $1.5 \%$.

Fruit dipped in calcium at 2.5 and $3.5 \%$ showed higher levels of TA, respectively than that obtained with untreated fruit but they did not vary among each other. Calcium infiltration treatments at 3.5 and $1.5 \%$ were able to maintain acidity levels Table 3 . The decrease in total acidity in papaya during ripening is probably due to the decrease in citric acid. Selvaraj et $a l{ }^{[44]}$ reported that citric acid decreased by two thirds during fruit maturation with little changes in the ripening phase. In this since, retarding the papaya fruit ripening by calcium causing inhibition of enzyme activity could explain the delay in the use of organic acids in the enzymatic reactions of respiration. Our result confirms that obtained by Cheour et al. ${ }^{[7]}$ who reported that the quantity of organic acids expressed as citric acid decreased in strawberry fruits during storage. 
Calcium treatment delayed the decrease in the citric acid, the effect of $\mathrm{Ca}$ was observed after 14 days of storage.

Ascorbic acid: Ascorbic acid was found to maintain with postharvest application of calcium, it was higher with infiltration treatments than that obtained with dip treatments compared to the control treatment (Table 5). Calcium infiltration treatments with 2.5 and $3.5 \%$ had the highest contents of ascorbic acid compared with untreated fruit. However, they did not show any significant difference between each other. On the other hand, calcium infiltration at $3.5 \%$ did not have significant differences with calcium infiltration at $1.5 \%$ and dip treatments at 2.5 and $3.5 \%$, respectively. Calcium dip treatments at $2.5,3.5$ and $1.5 \%$ slightly maintained the loss of ascorbic acid compared to the control treatment. However, no significant difference was found between treatments excluding control.

For papaya ascorbic acid, it first increases during ripening then decreases during senescence. It has been indicated that once fruits reach ripe stage, ascorbic acid contents start to decline ${ }^{[26,44]}$. Similar result was obtained by Mathooko ${ }^{[29]}$ who reported that the ascorbic acid content in tomato increased with maturity and ripening. However, once fruit became fully ripe, the vitamin content started to decline Table 4.

Laufinan and Sams ${ }^{[25]}$ treated apple with 0 to $4 \%$ $\mathrm{CaCl}_{2}$ and stored the fruit at $2{ }^{\circ} \mathrm{C}$ and found that ascorbic acid content ranged between $200-400 \%$ in calcium treated fruit as compared to the control. Sams et al. ${ }^{[41]}$ Infiltrated the apple with $\mathrm{CaCl}_{2}$ and increased calcium contents from 200-2400 g, they found that $\mathrm{CaCl}_{2}$ treated fruit were firmer and had more ascorbic acid than untreated fruit.

Disease incidence: Table 5 shows that maximum rot $93.42 \%$ was found in untreated papaya fruit. Whereas, the minimum rot $39.07 \%$ was observed at 25 days storage by calcium infiltration treatment $2.5 \%$. Calcium infiltration treatment at $2.5 \%$ controlled rottening compared to $\mathrm{Al}$ other treatments. Calcium infiltration treatments at 3.5 and $1.5 \%$ were superior to the other treatments in controlling postharvest rot by 56 and $64.21 \%$, respectively compared with untreated fruit. The least control in decay was found in dip treatments at $2.5,3.5$ and $1.5 \%$ by $72.33,76.42$ and $84.46 \%$ rot, respectively. However, calcium dip treatments did not show significant difference with untreated fruit.

Calcium chloride treatment resulted in a reduction of rot decay. Beneficial effects of calcium against postharvest decay have been shown for various fruit species $^{[11,41]}$. Conway et al. ${ }^{[10]}$ have reported that the
Table 4: Effects of different concentrations and applications of calcium on soluble solids concentrations, $\mathrm{pH}$ and titrtable acidity contents of papaya fruit after 21 days of storage at $13 \pm 1^{\circ} \mathrm{C}$

\begin{tabular}{llllc}
\hline Treatments & & SSC $\left({ }^{\circ}\right.$ Brix $)$ & $\mathrm{pH}$ & Titratable acidity (\%) \\
\hline Control & $0 \%$ & $14.0 \mathrm{a}$ & $5.7 \mathrm{a}$ & $0.16 \mathrm{f}$ \\
Dip & $1.5 \%$ & $13.6 \mathrm{ab}$ & $5.2 \mathrm{~b}$ & $0.17 \mathrm{e}$ \\
& $2.5 \%$ & $12.9 \mathrm{~cd}$ & $4.9 \mathrm{bcd}$ & $0.19 \mathrm{~d}$ \\
\multirow{4}{*}{ Infiltration } & $3.5 \%$ & $13.3 \mathrm{bc}$ & $5.1 \mathrm{bc}$ & $0.19 \mathrm{~d}$ \\
& $1.5 \%$ & $12.6 \mathrm{~d}$ & $4.7 \mathrm{~cd}$ & $0.21 \mathrm{c}$ \\
& $2.5 \%$ & $11.4 \mathrm{e}$ & $4.5 \mathrm{~d}$ & $0.23 \mathrm{a}$ \\
LSD & $3.5 \%$ & $11.8 \mathrm{e}$ & $4.7 \mathrm{~d}$ & $0.22 \mathrm{~b}$ \\
\hline
\end{tabular}

Means with the same letters within a column are not significantly different at $\mathrm{p} \leq 0.05$ using LSD. Each value is the mean for five replicates

Table 5: Effects of different concentrations and applications of calcium on ascorbic acid contents after 21 days and disease incidence percentage after 26 days of storage of papaya fruits at $13 \pm 1^{\circ} \mathrm{C}$

\begin{tabular}{|c|c|c|c|}
\hline Treatments & & \multirow{2}{*}{ 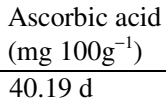 } & \multirow{2}{*}{$\begin{array}{l}\begin{array}{l}\text { Disease } \\
\text { incidence }(\%)\end{array} \\
93.42 \mathrm{a}\end{array}$} \\
\hline Control & $0 \%$ & & \\
\hline Dip & $1.5 \%$ & $41.38 \mathrm{~cd}$ & $84.46 \mathrm{ab}$ \\
\hline & $2.5 \%$ & $44.25 \mathrm{bcd}$ & $72.33 \mathrm{bc}$ \\
\hline & $3.5 \%$ & $43.36 \mathrm{bcd}$ & $76.42 \mathrm{bc}$ \\
\hline \multirow[t]{3}{*}{ Infiltration } & $1.5 \%$ & $45.83 \mathrm{bc}$ & $64.21 \mathrm{~cd}$ \\
\hline & $2.5 \%$ & $51.75 \mathrm{a}$ & $39.07 \mathrm{e}$ \\
\hline & $3.5 \%$ & $47.10 \mathrm{ab}$ & $56.00 \mathrm{~d}$ \\
\hline LSD & & 5.10 & 15.45 \\
\hline
\end{tabular}

Means with the same letters within a column are not significantly different at $\mathrm{p} \leq 0.05$ using LSD. Each value is the mean for five replicates

changes in firmness indicated a degradation of the apple cell walls and consequent reduction in fruit quality. Additionally, the loss of firmness due to cell wall carbohydrate metabolism during storage has been associated with increased susceptibility to infection by fungal pathogens.

Shear and Faust ${ }^{[46]}$ reported that calcium not only protects apple from the physiological disorders, but also help in reducing decay, by strengthening the cell wall and regulating the metabolic activity in the fruit. Control of these metabolic activities, increase fruit quality and extend postharvest life of fruit. Gallerani et al..$^{[14]}$ treated apples with 4 and $8 \%$ calcium chloride solution through dip and vacuum dip methods. After the treatment the apples were stored at ambient temperature $\left(20^{\circ} \mathrm{C}\right)$. The $4 \%$ $\mathrm{CaCl}_{2}$ vacuum infiltration treatment was better in controlling bitter pit and in keeping fruit firm. They also found that calcium infiltration at pressure is better than simple immersion.

Conway $^{[8]}$ treated delicious apple with $0,2,4,6$, or $8 \%$ calcium chloride by dipping and vacuum infiltration. The apples were kept for 3 months in storage at $0^{\circ} \mathrm{C}$. After storage, the fruits were inoculated with conidial suspension of Penicillium expansum and 
kept at $20^{\circ} \mathrm{C}$ for 7 days. Least decay and maximum calcium content in the fruits was found in $8 \%$ calcium chloride infiltrated fruit. Conway and Sams ${ }^{[9]}$ pressure infiltrated Golden Delicious apples with 0, 2, 4, 6, or $8 \% \mathrm{CaCl}_{2}$ solution and stored the fruit at $0^{\circ} \mathrm{C}$. After 6 months of cold storage, they found that $\mathrm{CaCl}_{2} 4,6,8 \%$ treatments resulted in $50 \%$ less decay than untreated fruit.

\section{CONCLUSION}

This work suggests that postharvest vacuum infiltration of papaya fruits in $2.5 \% \mathrm{CaCl}_{2}$ benefits storage life capacity and maintains quality characteristics, shows better effects than with other concentrations and with calcium dip treatments. Therefore, the calcium infiltration with different concentrations combined with chitosan coating needs to be investigated in terms of its ability in storage and maintaining quality of papaya.

\section{REFERENCES}

1. Abbott, J.A., W.S. Conway and C.E. Sams, 1989. Postharvest calcium chloride infiltration affects textural attributes of apples. J. Am. Soc. Hort. Sci., 114: 932-936.

2. Agar, I.T., R. Massantini, B. Hess-Pierce and A.A. Kader, 1999. Postharvest $\mathrm{CO}_{2}$ and ethylene production and quality maintenance of fresh cut kiwifruit slices. J. Food Sci., 64: 433-440.

3. Andrea, L.B.D., S.D. Quintao Scalon, I.F.C. Maria and A.B. Chitarra, 1999. Postharvest application of $\mathrm{CaCl}_{2}$ in strawberry fruits (Fragaria Ananassa Dutch cv. Sequoia): Evaluation of fruit quality and postharvest life. Cienc Agrotec Lavras., 23: 841-848.

4. Asrey, R.K., Jain and R. Singh, 2004. Effect of preharvest chemical treatment on shelf life of Chandler strawberry (Fragaria×ananassa). J. Agric. Sci., 74 (9): 485-487.

5. Chaplin, G.R. and K.J. Scott, 1980. Association of calcium in chilling injury susceptibility of stored avocados. Hortscience, 15: 514-515.

6. Cheour, F., C. J. Willemot, Y. Arul, J. Desjardins, P.M. Makhlouf, P. and A. Gosselin, 1990. Effects of foliar application of $\mathrm{CaCl}_{2}$ on postharvest strawberry ripening. J. Am. Soc. Hort. Sci., 115: 789-792.

7. Cheour, F., C.J. Willemot, Y. Arul, P.M Makhlouf and Y. Desjardins, 1991. Postharvest response of two strawberry cultivars to foliar application of $\mathrm{CaCl}_{2}$. Hort. Sci., 26: 1186-1188.

8. Conway, W.S., 1982. Effect of postharvest calcium treatment on decay of Delicious apples. Plant Dis., 66: 402-403.

9. Conway, W.S. and C.E. Sams, 1983. Calcium infiltration of Golden Delicious apples and its effect on decay. Phytopathology, 73: 1068-1071.
10. Conway, W.S., K.C. Gross and C.E. Sams, 1987. Relationship of bound calcium and inoculum concentration to the effect of postharvest calcium treatment on decay of apples by Penicillium expansum. Plant Dis., 71: 78-80.

11. Conway, W.S., C.E. Sams, R. McGuive and A. Kelman, 1992. Calcium treatment of apples and potatoes to reduce postharvest decay. Plant Dis., 76: 329-334.

12. Coseteng, M.Y. and C.Y. Lee, 1987. Changes in apple polyphenoloxidase and polyphenol concentrations in relation to degree of browning. J. Food Sci., 52: 985-989.

13. Dunn and A.J. Able, 2006. Preharvest calcium effects on sensory quality and calcium mobility in strawberry fruit. Acta Hortic., 708: 307-312.

14. Gallerani, G., G.C. Pratella, P. Bertolini and A. Marchi, 1990. Lake of relationship between total calcium of apple fruit and a calcium deficiency related disorder (bitter pit): A four year report. Acta Hortic., 274: 141-148.

15. Garcia, J.M., S. Herrera and A. Morilla, 1996. Effects of postharvest dips in calcium chloride on strawberry. J. Agric. Food Chem., 44: 30-33.

16. Goncalves, N.B., V.D. de Carvalho and J.R. de A. Goncalves, 2000. Effect of calcium chloride and hot water treatment on enzyme activity and content of phenolic compounds in pineapples. Pesquisa Agrop. Brasil., 35: 2075-2081.

17. Grant, G.T., ER. Morris, D.A. Rees, P.J.C. Smith and D. Thom, 1973. Biological interaction between polysaccharides and divalent cations: The egg box model. FEBS Lett, Kil., 32: 195-198.

18. Haard, N.F., 1988. Characteristics of Edible Plant Tissues. 2nd Edn., In: Food Chemistry. Fennema, O.R. (Ed.). Marcel Dekker, New York, pp: 857-911.

19. Hernandez-Munoz, E., M.J. Almenar, Ocio and R. Gavara, 2006. Effect of calcium dips and chitosan coating on postharvest life of strawberries (Fragaria $\times$ ananassa). Postharvest Biol. Technol., 39: 247-253.

20. Izumi, H. and A.E. Watada, 1994. Calcium treatments effect storage quality of shredded carrots. Food Sci., 59: 106-109.

21. John, M.A., 1987. Fruit Softening. In: Mangoes a Review, Prinsley R.T. and Tucker G., (Eds.) The Commonwealth Secretariat, London. pp: 98-106.

22. Jones, R.G.W. and O.R. Lunt, 1967. The function of calcium in plants. Botanical. Rev., 33: 407-426.

23. Krishna, M.R. and K. Purushotham, 2005. Extending the shelf life of papayas with chemical treatments and packages. First International Symposium on Papaya, 22-24 November, 2005, Genting Highlands, Malaysia, Organized by ISHS. 
24. Lara, I., P. Garcia and M. Vendrell, 2004. Modifications in cell wall composition after cold storage of calcium treated strawberry (Fragaria ananassa Duch.) fruit. Postharvest Biol. Technol., 34: 331-339.

25. Laufmann, J.E. and C.E. Sams, 1989. The effect of postharvest calcium treatment on polyphenol oxidase and peroxidase activity in golden delicious apples. HortScience., 24: 753-754.

26. Lazan, H., Z.M Ali and W.C. Sim, 1990. Retardation of ripening and development of water stress in papaya seal packaged with polyethylene film. Acta Hortcult., 269: 345-351.

27. Lester, G.E. and M.A. Grusak, 1999. Postharvest application of calcium and magnesium to honeydew and netted muskmelons: Effects on tissue ion concentrations, quality and senescence. J. Am. Soc. Hort. Sci., 124: 545-552.

28. Luna-Guzman, I., M. Cantwell and D.M. Barrett, 1999. Fresh cut cantaloupe: effects of $\mathrm{CaCl}_{2}$ dips and heat treatments on firmness and metabolic activity. Postharvest Biol. Technol., 17: 201-213.

29. Mathooko, F.M., 2003. A comparative study of the response of tomato fruit to low temperature storage and modified atmosphere packaging. African J. Food, Agric., Nut. Dev., 2: 34-41.

30. Mignani. I., L.C. Greve, R. Ben-Arie, H.U. Stotz, C. Li, K. Shakel and J. Labavitch, 1995. The effect of GA and divalent cations on aspects of pectin metabolism and tissue softening in ripening tomato pericarp. Physiol. Plant, 93: 108-115.

31. Morris, E.R., 1980. Physical probes of polysaccharide conformations and interactions. Food Chem., 6: 15-39.

32. Morris, J.R., W.A. Sistrunk, C.A. Sims and G.L. Main, 1985. Effects of cultivar, postharvest storage, preprocessing dip treatments and style of pack on the processing quality of strawberries. J. Am. Soc. Hort. Sci., 110: 172-177.

33. Picchion, G.A., A.E. Watada, W.S. Conway, B.D. Whitaker and C. E. Sams, 1998. Postharvest calcium infiltration delays membrane lipid catabolism in apple fruit. J. Agric. Food Chem., 46: 2452-2457.

34. Rajkumar, M. and K. Manivannan, 2005. Effect of chemicals and growth regulator on postharvest behaviour of papaya (Carica papaya cv. $\mathrm{CO}_{2}$ ). First International Symposium on Papaya, 22-24 November, 2005, Genting Highlands, Malaysia, Organized by ISHS.

35. Ranganna, S., 1977. Manual of Analysis of Fruit and Vegetable Products. McGraw- Hill,New Delhi.

36. Rohani, M.Y., M.Z. Zaipun and M. Norhayati, 1997. Effect of modified atmosphere on the storage life and quality of Eksotika papaya. J. Trop. Agric. Food Sci., 25: 103-113.
37. Rosen, J.C. and A.A. Kader, 1989. Postharvest physiology and quality maintenance of sliced pear and strawberry fruits. J. Food Set., 54: 656-659.

38. Saftner, R.A., W.S. Conway and C.E. Sams, 1998. Effect of postharvest calcium and fruit coating treatments on postharvest life, quality maintenance and fruit surface injury in Golden Delicious apples. J. Am. Soc. Hort. Sci., 123: 294-298.

39. Sams, C.E. and W.S. Conway, 1984. Effect of calcium infiltration on ethylene production, respiration and quality of Golden Delicious apple fruit. J. Am. Soc. Hort. Sci., 109: 53-57.

40. Sams, C.E. and W.S. Conway, 1993. Postharvest calcium infiltration improves fresh and. processing quality of apples. Acta Horticult., 32: 123-129.

41. Sams, C.E., S.W. Conway, J.A. Abbott, R.J. Lewis and N. Benshalom, 1993. Firmness and decay of apples following postharvest pressure infiltration of calcium and heat treatment. J. Am. Soet Horde. Set., 118: 623-627.

42. SAS Institute, 1989. Users Guide: Statistic Version 8.02 SAS Institute, Inc. Carey, NC, USA.

43. Scott, K.J. and B.H. Wills, 1979. Effects of vacuum and pressure infiltration of calcium chloride and storage temperature on the incidence of bitter pit and low temperature breakdown of apples. Aust. J. Agric. Res., 30: 917-928.

44. Selvaraj, Y., D.K. Pal, M.D. Subramaniam and C.P.A. Iyer, 1982a. Changes in the chemical composition of four cultivars of papaya during growth and development. J. Hortic. Sci., 57: $135-143$.

45. Sharpels, R.O. and D.S. Johnson, 1977. The influence of calcium on senescence changes in apples. Ann. Applied Biol., 85: 150-453.

46. Shear, C. B. and M. Faust, 1975. Preharvest nutrition and postharvest physiology of apples. In Symposium :Postharvest Biology and Handling of Fruits and Vegetables, N.F. Hard and D.K. Salunkhe, (Eds.). The AVI Publishers Company, Inc. Westport, CT.

47. Shukor, A.R.A. and A.O. Shokri, 1997. Respiratory activity and compositional changes in Eksotika papaya fruit following storage in low-oxygen atmosphere. J. Trop. Agric. Food Sci., 25: 85-93.

48. Suntharalingam, S., 1996. Postharvest treatment of mangoes with calcium. Trop. Sci., 36: 14-17.

49. Wills, R.B.H., S.I.H. Tirmazi and K.J. Scott, 1977. Use of calcium to delay ripening of tomatoes. HortScience, 12: 551-552.

50. Wilnwright, H. and B.M. Burbage, 1989. Physiological disorders in mango (Mangifera indica L) fruit. J. Horticult Sci., 64: 125-135. 